\title{
FIA-FAAS Method for Tannin Determination Based on a Precipitation Reaction with Hemoglobin
}

\author{
Edilene C. Ferreira ${ }^{a, b}$, Gilberto B. Souza ${ }^{a, c}$ and Ana Rita A. Nogueira ${ }^{*, a}$ \\ ${ }^{a}$ Grupo de Análise Instrumental Aplicada - Embrapa Pecuária Sudeste, CP 339, 13560-970 São Carlos - SP, Brazil \\ ${ }^{b}$ Departamento de Química, Universidade Federal de São Carlos, CP 676, 13565-905 São Carlos - SP, Brazil \\ ${ }^{c}$ Instituto de Química de São Carlos, Universidade de São Paulo, CP 780, 13560-970 São Carlos - SP, Brazil
}

\begin{abstract}
Um sistema em fluxo acoplado a espectrômetro de absorção atômica com chama (FIA-FAAS) foi desenvolvido para determinação de taninos em amostras de feijão guandu, explorando a reação de precipitação entre os taninos e proteínas. Extratos obtidos pela sonicação das amostras com solução de metanol 50\% (v/v), foram introduzidos no sistema e induzidos à reação com hemoglobina, sendo o precipitado produzido pela reação retido em um filtro localizado no percurso analítico. Solução $1 \%$ $(\mathrm{m} / \mathrm{v})$ dodecil sulfato de sódio, fluindo em sentido inverso ao fluxo de filtração, foi empregado para solubilizar e conduzir o complexo tanino-hemoglobina ao detector, espectrômetro de absorção atômica com chama, para quantificação dos íons ferro presentes na estrutura da hemoglobina. Uma solução de ácido tânico foi utilizada para construção da curva analítica. O método proposto apresentou frequiência analítica de 30 amostras por hora, desvio padrão relativo de 9,7 \% (n=10) e limite de quantificação $0,27 \mathrm{mg} \mathrm{L}^{-1}$ de ácido tânico.
\end{abstract}

A flow system, coupled with flame atomic absorption spectrometry (FIA-FAAS), was developed for tannin determination in pigeon pea samples, exploring the precipitation reaction between tannins and proteins. Sample extracts obtained by sonication with a $50 \%(\mathrm{v} / \mathrm{v})$ methanol solution were introduced into the system and induced to react with a hemoglobin solution. The precipitate produced was retained on a filter located in the analytical flow. A reversed flow of $1 \%(w / v)$ sodium dodecyl sulfate solution was used for solubilization of the precipitate from the filter and to conduct the tanninhemoglobin complex to the FAAS, to quantify the iron ions present in the hemoglobin structure. A tannic acid solution was used to prepare the analytical curve. The proposed method allowed determination of 30 samples per hour, a standard deviation of $9.7 \%(n=10)$, and a quantification limit of $0.27 \mathrm{mg} \mathrm{L}^{-1}$ for tannic acid.

Keywords: tannin-protein complexes, hemoglobin, FIA, flame atomic absorption spectrometry

\section{Introduction}

The term tannin originated from "tanning", an expression which refers to tan animal skin. ${ }^{1}$ This is possible because tannins link to collagen, which is the protein present in animal skin. ${ }^{2}$ Thus, the ability to link and precipitate proteins is a property that defines tannins. For this reason, the reaction between tannins and protein has been used in many analytical methods for tannin determination, ${ }^{3-6}$ especially when results that measure the correlation with the nutritional value of food are desired. ${ }^{7}$ Moreover, this reaction is very specific, which minimizes interference effects in an analytical method.

* e-mail: anarita@cppse.embrapa.br
Tannin-protein complexes are dissolved by detergents, that break hydrophobic interaction between them, or by high $\mathrm{pH}$ values that ionize hydroxyphenolic groups so that it becomes unable to maintain the hydrogen bonding. ${ }^{4}$ Usually tannin-protein precipitates are dissolved using sodium dodecyl sulfate. ${ }^{7}$

Bate-Smith ${ }^{6}$ proposed the use of hemoglobin for tannin determination as a chromoprotein in a spectrophotometric methodology. Later, Schultz et al. ${ }^{8}$ suggested this reaction for quantitative analysis of tannins and described some advantages (water soluble and some buffering ability) in using hemoglobin, compared to other proteins. On the other hand, these methods were considered difficult for routine application because they require large amounts of fresh blood and some colored compounds from samples or blood 
could seriously interfere in the mesurements. ${ }^{7}$

Flow methods have proven to be suitable for many analytical applications due to low sample and reagent consumption, high sample throughput and the feasibility of their implementation. With this kind of system, a large number of chemical manipulations may be carried out in a contamination-free system with good precision. ${ }^{9}$ The combination of flow methods and atomic spectrometry is successful because, in these system, interference effects are overcome, firstly by the exploitation of some inherent feature of flow injection (FI), such as the use of a continuous carrier stream or micro-sample volume and secondly, since interferences may be alleviated by the implementation of some pretreatment chemistry in the FI format. Many of the limitations from which atomic spectrometry procedures suffer could be overcome by the separation of the analyte species from the unwanted matrix species. Often such separation procedures also result in increased analyte mass flux into the atom source, with consequent improvements in sensitivity and detection limits. ${ }^{10}$

In this work the advantages of quantifying tannins by exploring their precipitation reaction with proteins was investigated. Color interference was prevented by the use of flame atomic absorption spectrometry (FAAS) as measurement technique. A flow injection ${ }^{9}$ procedure was developed to automate the determinations and to improve the reaction conditions. The main parameters involved in the determination were evaluated and the system was applied to pigeon pea (Cajanus cajan [L] Millsp) samples.

\section{Experimental}

\section{Instrumental}

A freeze drier (Savant model Novalyphe NL 150, New York, USA), and a freezer mill (Spex Certiprep model 6750, Metushen, NJ, USA), which operated at liquid nitrogen temperature, were used for sample drying and grinding, respectively. An ultrasound bath (Unique model USC 1400) and a centrifuge (Fanem model 204 NR, São Paulo, Brazil) were used to, respectively extract and separate the tannin from pigeon pea samples. A spectrophotometer (Femto 432, São Paulo, Brazil) was used to determine nitrogen for achieving the stoichiometric relationship between tanninhemoglobin and to perform the manual comparative assay.

The flow setup presented in Figure 1 comprised a model ISM 761 peristaltic pump (Ismatec, Zürich, Switzerland) furnished with Tygon pumping tubes and an automatic injector-commutator (Micronal, model B-352, São Paulo, Brazil), to introduce sample and hemoglobin solutions into the system. A controlled-temperature bath (Fanem,
São Paulo, Brazil) was used to ensure a constant temperature $\left(40{ }^{\circ} \mathrm{C}\right)$ to speed up the reaction.

The manifold, built with $0.8 \mathrm{~mm}$ i.d. polyethylene tubing having a non-collapsible wall and Perspex ${ }^{\circledR}$ Yshaped connectors, was coupled to a Varian SpectrAA-800 atomic absorption spectrometer (Varian, Mulgrave, Australia). An iron hollow cathode lamp from the same manufacturer was used for measurements of absorption signals, working with $5 \mathrm{~mA}$ of current. The analytical wavelength was the $248.3 \mathrm{~nm}$ iron resonance line, selected with a spectral band pass of $0.2 \mathrm{~nm}$. The background was corrected with a deuterium lamp. An air/acetylene flame (13.5:2 $\mathrm{L} \mathrm{min}^{-1}$ ) was used for all measurements, which were based on peak area measured for $30 \mathrm{sec}$.

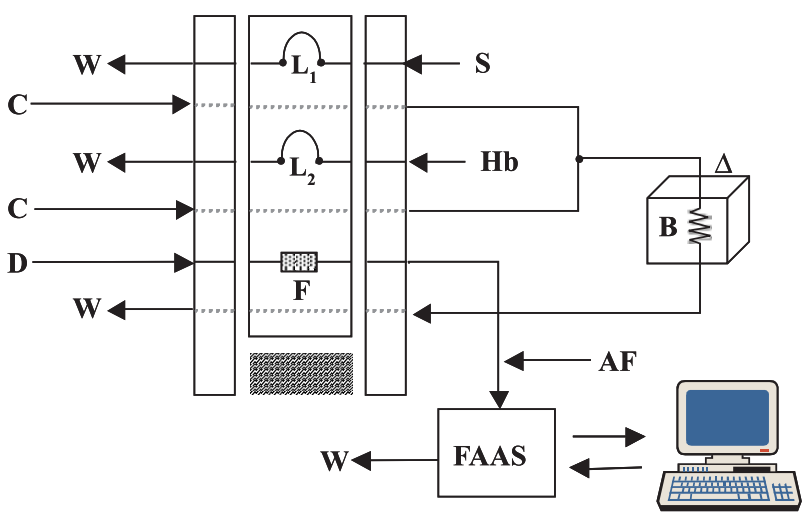

Figure 1. Flow System: $\mathbf{S}$, sample; $\mathbf{H b}$, hemoglobin solution; $\mathbf{L}_{\mathbf{1}}$, loop of sample extract; $175 \mathrm{~cm}(c a .875 \mu \mathrm{L}) ; \mathbf{L}_{2}$, loop of hemoglobin solution, $175 \mathrm{~cm}($ ca. $875 \mu \mathrm{L})$; W, waste, $\mathbf{C}$, carrier streams, $2.0 \mathrm{~mL} \mathrm{~min}^{-1}$ each (buffer solution Tris/HCl, $0.05 \mathrm{~mol} \mathrm{~L}^{-1}, \mathrm{pH} 7.00$, containing $100 \mathrm{mg} \mathrm{L}^{-1}$ tannic acid), B, reaction coil, $150 \mathrm{~cm}$ (ca. $750 \mu \mathrm{L}$ ), $\Delta$ heating at $40{ }^{\circ} \mathrm{C}, \mathbf{F}$, filter, D, diluent solution, $2.0 \mathrm{~mL} \mathrm{~min}^{-1}(1 \%(\mathrm{w} / \mathrm{v}) \mathrm{SDS}), \mathbf{A F}$, auxiliary flow at $4.3 \mathrm{~mL} \mathrm{~min} \mathrm{~m}^{-1}$ $(1 \%(\mathrm{w} / \mathrm{v}) \mathrm{SDS})$

\section{Solutions}

All solutions were prepared from analytical grade reagents, and distilled, deionized water was used throughout.

In the flow diagram in Figure 1, the extraction solution (ES) was prepared by mixing absolute methanol with water $50 \%(\mathrm{v} / \mathrm{v}){ }^{6,7}$

Hemoglobin solution $(\mathrm{Hb})$ was freshly prepared by dissolution of $0.1 \mathrm{~g}$ of bovine hemoglobin (Sigma, St. Louis, MO, USA) in $100.0 \mathrm{~mL}$ of $0.05 \mathrm{~mol} \mathrm{~L}^{-1}$ Tris/ $\mathrm{HCl}$ buffer, $\mathrm{pH}$ 7.0. The Tris- $\mathrm{HCl}$ buffer solution was prepared by solubilization of $6.05 \mathrm{~g}$ of tris-(hydroxymethyl) aminomethane (Reagen, Rio de Janeiro, Brazil) in approximately $800 \mathrm{~mL}$ of $\mathrm{H}_{2} \mathrm{O}$. The $\mathrm{pH}$ was adjusted with $0.10 \mathrm{~mol} \mathrm{~L}^{-1} \mathrm{HCl}$ solution to 7.0. The final volume was then made up to $1000 \mathrm{~mL}$ with water. 
Carrier solution (C) was prepared by dissolution of 0.1 $\mathrm{g}$ of tannic acid (Sigma) in $100.0 \mathrm{~mL}$ of Tris/HCl buffer (0.05 mol L-1, $\mathrm{pH} 7.00)$. Diluent solution (D) was prepared by dissolution of $1.0 \mathrm{~g}$ sodium dodecyl sulfate (SDS Synth, Diadema SP, Brazil) in $100.0 \mathrm{~mL}$ of water.

The analytical standard solutions $(0.00,200.0,400.0$, 600.0 and $800.0 \mathrm{mg} \mathrm{L}^{-1}$ ) were prepared by appropriate dilutions of the stock solution containing $5.0 \mathrm{~g} \mathrm{~L}^{-1}$ of tannic acid in ES medium.

\section{Samples}

Pigeon pea (Cajanus cajan [L] Millsp) leaves and pod samples were obtained from a genetic improvement experiment. ${ }^{11}$ Leaves samples, termed L1 - L6, and pods, termed P1 - P3, were harvested under ice and washed with cold distilled water. The samples were then freeze-dried after freezing with liquid nitrogen at $-196{ }^{\circ} \mathrm{C}$. The dried samples were ground in the freezer mill, after $3 \mathrm{~min}$ of precooling with 2 min of grinding. Three grinding cycles were performed and a cooling step of 1 min was applied between the cycles.

A mass of $0.2 \mathrm{~g}$ (dry weight) of ground samples received $10 \mathrm{~mL}$ of the extraction solution (ES). The mixture was sonicated in an ultrasonic bath for $30 \mathrm{~min}$, followed by 20 min of centrifugation at $693 \mathrm{~g}$.

\section{Flow system}

At the position indicated in the flow-setup in Figure 1, the sample extract $\left(\mathrm{L}_{1}, 175 \mathrm{~cm}\right.$, about $\left.875 \mu \mathrm{L}\right)$, and hemoglobin solution $\left(\mathrm{L}_{2}, 175 \mathrm{~cm}\right.$, about $\left.875 \mu \mathrm{L}\right)$ were aspirated. By switching the injector, the sample extract and hemoglobin aliquots were introduced into the carrier streams (C, $2.0 \mathrm{~mL} \mathrm{~min}^{-1}$ each), flowing into a confluence point. This sample zone passed through the reaction coil (B, $150 \mathrm{~cm}$, about $750 \mu \mathrm{L}$ ) immersed in a water bath at $40{ }^{\circ} \mathrm{C}$. Afterwards, the flow containing tannin-hemoglobin complex passed into a filter (F) built into glass tubing (20 cm length and $1.5 \mathrm{~mm}$ i.d.), filled with glass wool, where the precipitate was retained. Again switching the injector, diluent solution (D) passed through the filter, dissolving and conducting the complex to the FAAS, where Fe ions from hemoglobin were quantified. The tannin amount can then be indirectly determined. The system was experimentally optimized based on factorial plans and response surface methodologies. ${ }^{12}$

\section{Stoichiometric relationship determination}

The stoichiometric relation between hemoglobin and tannic acid was determined through total nitrogen analysis in the precipitate formed by reaction between them. Tannic acid $\left(1.0 \mathrm{~g} \mathrm{~L}^{-1}\right)$ and hemoglobin solution $\left(1.0 \mathrm{~g} \mathrm{~L}^{-1}\right)$ were mixed at different ratios: 1:0.5, 1:1, 1:1.25, 1:1.5, 1:2, 1:3, and 1:4 (tannic acid: hemoglobin). The resulting precipitates were filtered using quantitative paper filter (Whatman 540, $8 \mu \mathrm{m}$ and $12.5 \mathrm{~cm}$ diameter). Each filter paper containing the precipitate was placed in a $100 \mathrm{~mL}$ digestion vessel and $15 \mathrm{~mL}$ of concentrated $\mathrm{H}_{2} \mathrm{SO}_{4}$ plus $0.7 \mathrm{~g}$ of $\mathrm{K}_{2} \mathrm{SO}_{4} / \mathrm{CuSO}_{4}$ (1:10) catalytic mixing were added. The vessel was then transferred to a heating block and carefully heated until the beginning of the reaction. After that, the temperature was increased up to $400{ }^{\circ} \mathrm{C}$ until formation of a colorless solution, after which heating was maintained for $1 \mathrm{~h}$. The blank solution was obtained by digestion of filter paper containing no sample. After digestion, the acid solutions were evaporated to obtain nearly $2 \mathrm{~mL}$, cooled and then diluted to $50 \mathrm{~mL}$ with water. Nitrogen amount was determined in each solution by the Berthelot reaction in a previously described flow procedure. ${ }^{13}$

\section{Manual assay}

The comparative manual assay was based on the method proposed by Schultz et al., ${ }^{8}$ with a few modifications. Commercial bovine hemoglobin was used, instead of fresh blood.

In a centrifuge tube, $1.0 \mathrm{~mL}$ of sample extract, $1.0 \mathrm{~mL}$ of water and $1.0 \mathrm{~mL}$ of hemoglobin solution $\left(1.0 \mathrm{~g} \mathrm{~L}^{-1}\right)$ were mixed in a vortex mixer for $20 \mathrm{~min}$ and decanted. The samples were then centrifuged for $20 \mathrm{~min}$ at $693 \mathrm{~g}$. The precipitate was separated and dissolved with $4.0 \mathrm{~mL}$ of 5\% (w/v) SDS solution. The resulting colored solution was analyzed in the spectrophotometer at $578 \mathrm{~nm}$.

\section{Results and Discussion}

The results of tannin concentration obtained using the proposed FIA-FAAS method and that obtained by using the manual assay are shown in Table 1. The results obtained with the later method were different than those obtained with the flow approach. This occurred because there were small differences among the standard absorbances in the manual procedure, which causes a lesser slope $(\mathrm{m}=9.35 \mathrm{x}$ $10^{-5}$ ) in the analytical curve, compared with that obtained by the FIA-FAAS method $\left(\mathrm{m}=5.3 \times 10^{-4}\right)$. This small difference between absorbance values could induce erroneous results, mainly owing the small amount of tannin present in pigeon pea plants.

To explain the sensitivity differences, the stoichiometric relationship between tannic acid and hemoglobin 
Table 1. Tannin concentration $\left(\mathrm{g} \mathrm{kg}^{-1}\right.$ of tannic acid) determined by the proposed system (FI) and by the manual approach in leaves (L1L6) and pods (P1 - P3) of pigeon pea samples

\begin{tabular}{ccc}
\hline Sample & FIA-FAAS $(\mathrm{n}=2)$ & Manual $(\mathrm{n}=3)$ \\
\hline L1 & $29.8(5.2)^{\mathrm{a}}$ & $48.3(1.6)$ \\
L2 & $55.7(4.7)$ & $44.8(6.3)$ \\
L3 & $10.9(8.9)$ & $48.0(10.5)$ \\
L4 & $41.9(7.1)$ & $22.7(0.4)$ \\
L5 & $56.1(6.6)$ & $32.5(3.4)$ \\
L6 & $30.5(9.7)$ & $19.4(1.9)$ \\
P1 & $26.9(2.8)$ & $31.9(3.9)$ \\
P2 & $67.4(2.2)$ & $36.0(6.1)$ \\
P3 & $90.8(2.0)$ & $49.7(0.2)$ \\
\hline
\end{tabular}

${ }^{\mathrm{a}} \mathrm{RSD}$ - relative standard deviation $(\%)$.

was evaluated. The results are presented in Figure 2. Greater amounts of nitrogen were detected in the precipitate obtained by mixing one part of tannic acid and two parts of hemoglobin, suggesting that this is the best condition for the tannin-hemoglobin reaction.

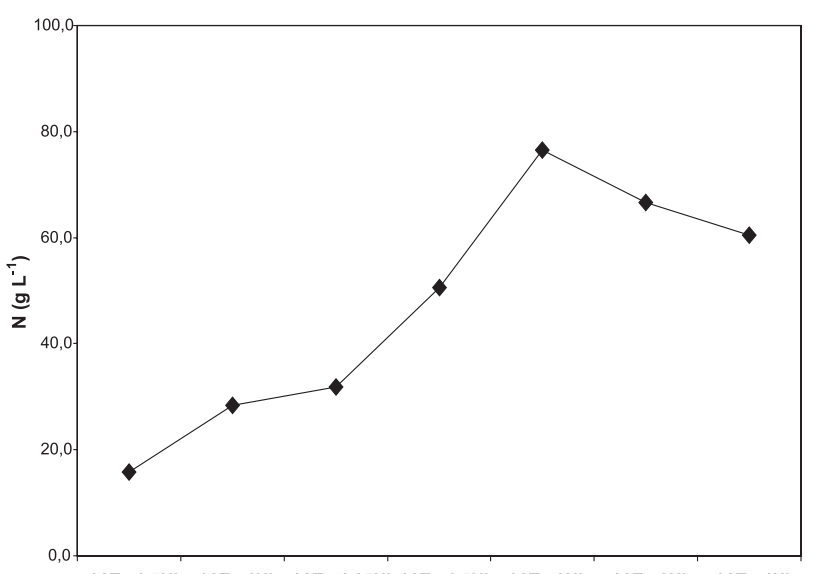

$1 \mathrm{AT}: 0.5 \mathrm{Hb} \quad 1 \mathrm{AT}: 1 \mathrm{Hb} \quad 1 \mathrm{AT}: 1.25 \mathrm{Hb} 1 \mathrm{AT}: 1.5 \mathrm{Hb} \quad 1 \mathrm{AT}: 2 \mathrm{Hb} \quad 1 \mathrm{AT}: 3 \mathrm{Hb} \quad 1 \mathrm{AT}: 4 \mathrm{Hb}$

Figure 2. Nitrogen amount $\left(\mathrm{g} \mathrm{L}^{-1}\right)$ determined with different ratios for forming the tannic acid-hemoglobin (TA:Hb) precipitate.

According to Spencer et al. ${ }^{14}$ the association of proteins and polyphenols is mainly a superficial phenomenon, and the bond efficiency is due to the fact that polyphenols are multidentate ligands able to bond simultaneously with more than one site on the protein surface through different phenolic groups. Hagerman and Butler ${ }^{15}$ suggested that the tannin-protein interaction occur through hydrogen bonds between donor phenolic groups and the acceptor peptide. Based on these evaluations, a probable model to explain tannic acid-hemoglobin interactions is:

$2 \mathrm{Hb}(\mathrm{aq})+1$ tannic acid $(\mathrm{aq}) \leftrightarrow \mathrm{Hb}$-tannic acid-Hb $\downarrow$
Thus, hydrogen atoms from phenolic groups of tannic acid act as electron-donor species, and a hydrogen atom from hemoglobin as acceptor, producing a more hydrophobic compound with higher molar mass, which precipites. This stoichiometric relationship, and some information about the hemoglobin structure, could explain the differences between the sensitivity of the manual spectrophotometric assay and the FIA-FAAS method.

The hemoglobin molecule is made up of four polypeptide chains (Alpha 1, Beta 1, Alpha 2, Beta 2), non-covalently bonded to each other. Each chain holds a heme group containing one $\mathrm{Fe}^{3+}$ ion. Consequently, there are four heme-iron complexes in a hemoglobin molecule (Figure 3). The heme-iron complexes are red, and are responsible for the red color of hemoglobin.$^{16}$
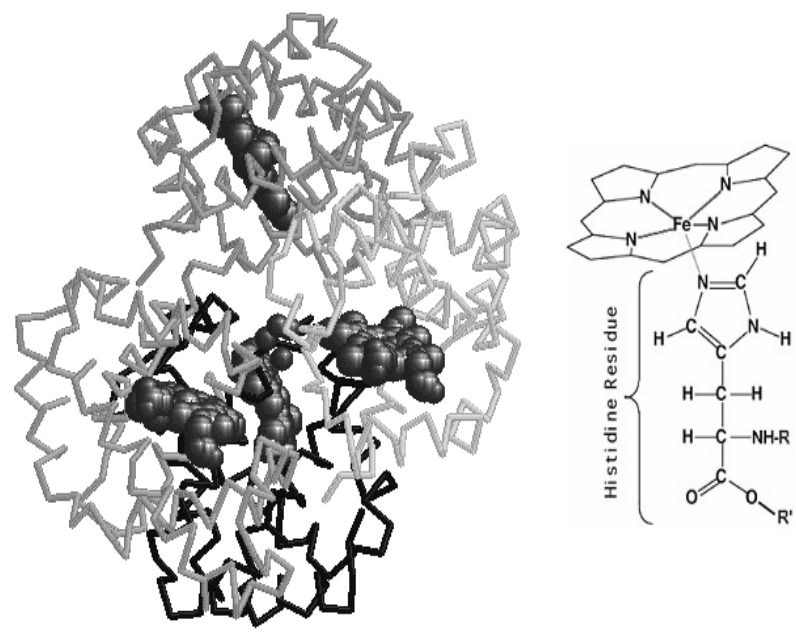

Figure 3. On the left, scheme of hemoglobin molecule represented by four polypeptide chains (Alpha 1, Beta 1, Alpha 2, Beta 2) and heme groups represented by spheres. On the right, a two-dimensional drawing of heme coordinated to a histidine residue, which is part of the hemoglobin protein. ${ }^{18}$

In both evaluated methods, the same amount of tannic acid and hemoglobin reagent was used. Thus, for each mol of $\mathrm{Hb}$-TA-Hb formed, two mols of hemoglobin are responsible for the color measured in the spectrophotometric assay, while in FIA-FAAS, for the same complex, eight mols of iron are responsible for the analytical signal in FAAS. Considering this relationship, FIA-FAAS could be four times more sensitive than the manual spectrophotometric assay, a very important characteristic, especially for samples with low amounts of tannin.

The parameters in the flow system, which interfere directly in the analytical signal, were optimized using chemometric methodologies, and the best conditions found are outlined in Figure 1. The addition of $0.1 \mathrm{mg} \mathrm{L}^{-1}$ of tannic acid in carrier solution improved the crystal seeding 
formation. ${ }^{17}$ An auxiliary flow (AF) was needed to interface the peristaltic flow with a Ventury effect nebulizer from FAAS. $^{10}$

The proposed methodology intended to reexamine the advantages of using hemoglobin for tannin precipitation, as described by Schultz et al. ${ }^{8}$ The use of commercial hemoglobin improved the method, reducing the manual steps, because it is easily diluted in Tris/ $\mathrm{HCl}$ buffer and more stable than that extracted from fresh blood. The detector used (FAAS) allowed the analysis of colored extracts, which is difficult to perform using methods with spectrophotometric detection.

The FIA-FAAS method presented an analytical frequency of 30 samples per hour, a relative standard deviation of $9.7 \%(n=10)$, and quantification limit for tannic acid of $0.27 \mathrm{mg} \mathrm{L}^{-1}$. This system can be used to determine total tannins in different kinds of samples. Other extraction solutions rather than $50 \%(\mathrm{v} / \mathrm{v})$ methanol could be used since no interference in precipitate formation takes place.

\section{Conclusions}

The proposed method combines the good characteristics of a flow system with the better sensitivity and selectivity offered by FAAS detection. The flow system allows the same kinetic reaction conditions for each sample, increasing the analytical velocity and, principally, improving sensitivity compared with the manual spectrophotometric assay. It also generates lower residues, compared with the manual methodology. The use of FAAS permits the tannin quantification in colored extracts.

\section{Acknowledgements}

The authors express their gratitude to Fundação de Amparo à Pesquisa do Estado de São Paulo - FAPESP for financial support (98/10814-3) and a fellowship provided to E. C. Ferreira (98/16062-3). A. R. A. Nogueira thanks the Conselho Nacional de Desenvolvimento Científico Tecnológico - CNPq for a researchship.

\section{References}

1. Hahn, D. H.; Rooney, L. W.; Earp, C. F.; Cereal Foods World 1984, 29, 776.

2. Butler, L. G.; Riedl D. J.; Lebryk, D. G.; Blytt, H. J.; J. Am. Oil Chem. Soc. 1978, 61, 679.

3. Bacon, J. R.; Rhodes, M. J. C.; J. Agric. Food Chem. 2000, 48, 838.

4. Hagerman, A. E.; Butler, L. G.; J. Agric. Food Chem. 1978, 26,809 .

5. Hagerman, A. E.; J. Chem. Ecol. 1987, 13, 437.

6. Bate-Smith, E. C.; Phytochemistry 1973, 12, 907.

7. Makkar, H. P. S.; J. Agric. Food. Chem. 1989, 37, 1197

8. Schultz, J. C.; Baldwin, I. T.; Nothnagle, P. J.; J. Agric. Food Chem. 1981, 29, 823.

9. Ruzicka, J.; Hansen, H.; Flow Injection Analysis, $2^{\text {nd }}$ ed., John Wiley \& Sons: New York, 1988.

10. Sanz-Medel, A., ed.; Flow Analysis with Atomic Spectrometric Detectors, Elsevier: Amsterdam, 1999.

11. Godoy, R.; Batista, L.A.R.; Negreiros, G.F.; Rev. Soc. Bras. Zoot. 1994, 23, 730

12. Eiras, S. P.; Cuelbas, C. J.; Andrade, J. C.; Quim. Nova 1994, 17, 216.

13. Nogueira, A.R.A.; Souza, G.; Batista, L.A.R.; Quim. Nova 1996, 19, 33.

14. Spencer, C. M.; Cai, Y.; Martin, R.; Gaffney, S. H.; Goulding, P. N.; Magnolato, D.; Lilley, T. H.; Haslam, E.; Phytochemistry 1988, 27, 2397.

15. Hagerman, A.E.; Butler L. G.; J. Biol. Chem. 1981, 256, 4494.

16. http://www.isat.jmu.edu/users/klevicca/isat454/ hemoglobin_essay.htm accessed in August 2001.

17. Brienza, S. M. B.; Sartini, R. P.; Gomes Neto J. A.; Zagatto, E. A. G.; Anal. Chim. Acta 1995, 308, 269.

18. http://wunmr.wustl.edu/EduDev/LabTutorials/Hemoglobin/ MetalComplexinBlood.html accessed in August 2001.

Received: October 19, 2002

Published on the web: March 21, 2003

FAPESP helped in meeting the publication costs of this article. 